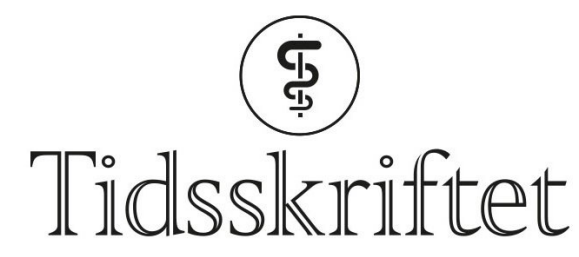

DEN NORSKE LEGEFORENING

\title{
Mange må behandles etter reflukskirurgi
}

FRA ANDRE TIDSSKRIFTER

PETTER PETTERsen

Sarpsborg

En ny studie fra Sverige viser at nesten én av fem som opereres for gastroøsofageal refluks får tilbakefall.

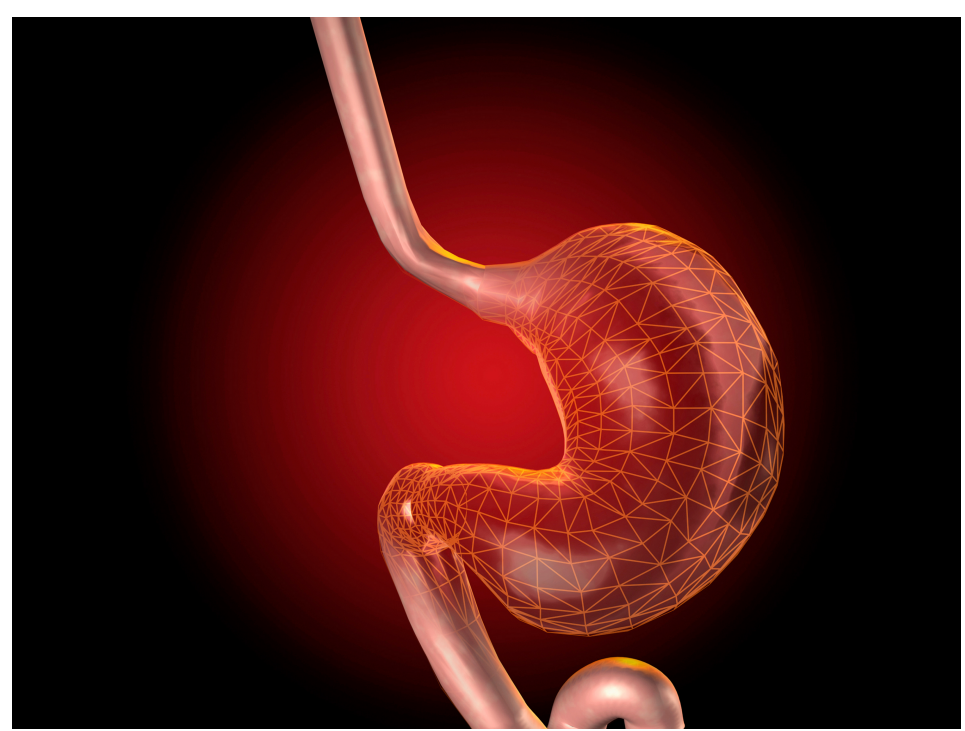

Illustrasjonsfoto: Science Photo Library

Dette viser tall fra den retrospektive nasjonale kohortstudien, som omfattet alle de 2655 svenske pasientene som ble behandlet med kikkhullskirurgi mot refluks i perioden 2005-14 (1). Tilbakefall ble i studien definert som reoperasjon eller medikamentell behandling mot refluks i minst et halvt år etter primæroperasjonen. Gjennom en median oppfølgingstid på 5,6 år fikk 17,7\% tilbakefall. Av disse fikk 83,6 \% medisiner, mens 16,4\% gjennomgikk en ny kikkhullsoperasjon mot refluks. Det ble funnet flest tilbakefall blant kvinner, eldre og pasienter med komorbide lidelser.

- Residivraten etter antireflukskirurgi varierer betydelig i forskjellige publikasjoner. Resultatet i denne studien er ikke overraskende ut ifra det som tidligere er publisert, svarer Gjermund Johnsen, overlege ved Gastrokirurgisk avdeling ved St. Olavs hospital.

- Resultatet er åpent for tolkning. Bruk av seks måneders medisinsk behandling med protonpumpehemmer eller $\mathrm{H} 2$-reseptorantagonist er et usikkert kriterium for residiv. I den aktuelle studien var et stort flertall av residivpasientene nettopp av denne kategorien. Både 
studier og egne erfaringer tilsier at et stort antall pasienter postoperativt foreskrives slik medikasjon for symptomer som ikke er betinget i reell gastroøsofageal refluks, legger Johnsen til.

LITTERATUR:

1. Maret-Ouda J, Wahlin K, El-Serag HB et al. Association Between Laparoscopic Antireflux Surgery and Recurrence of Gastroesophageal Reflux. JAMA 2017; 318: 939 - 46. [PubMed][CrossRef]

Publisert: 13. november 2017. Tidsskr Nor Legeforen. DOI: 10.4045/tidsskr.17.0851

(C) Tidsskrift for Den norske legeforening 2020. Lastet ned fra tidsskriftet.no 